УДК 342.5 (477)

\author{
Олег Валентинович Муза, \\ доктор юридичних наук, старший науковий співробітник, \\ професор кафедри кримінального та адміністративного права \\ Академії адвокатури України
}

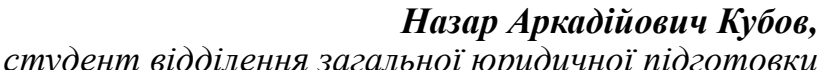
Академії адвокатури України

\title{
ДО ПИТАННЯ ПРО ЕФЕКТИВНІСТЬ ЗАКОНОДАВЧОГО РЕГУЛЮВАННЯ ДІЯЛЬНОСТІ ВІЙСЬКОВО-ЦИВІЛЬНИХ АДМІНІСТРАЦІЙ В УКРАЇНІ
}

Постановка проблеми. У зв'язку із проведенням Операції Об'єднаних сил (Антитерористичної операції) на Сході України виникло безліч проблем і питань, пов'язаних із здійсненням публічного управління. Така проблема вперше постала перед системою публічної влади і не мала аналогів в історії незалежної України. В умовах неприкритої зовнішньої агресії проти держави, фактичного стану окупації та воєнних дій, геополітичного протистояння законодавчо запроваджено спеціальну інституцію у системі органів публічного управління - військово-цивільні адміністрації (далі - ВЦА). Такі тимчасові державні органи створені з метою виконання повноважень органів місцевого самоврядування та місцевих органів виконавчої влади, забезпечення безпеки та нормалізації життєдіяльності населення, правопорядку, участі у протидії актам збройної агресії, диверсійним проявам, недопущенням гуманітарної катастрофи. При цьому, застосування законодавства про ВЦА потребує здійснення постійного правового моніторингу в умовах реальної ситуації, що склалася в окремих територіях Донецької і Луганської областей.

Аналіз останніх досліджень та публікацій. Питанню військово-цивільних адміністрацій в Україні присвячено незначну кількість праць (Р. Раімов, О. Сердюкова, О. Сікорський, В. Шевченко), що й зумовлює необхідність проведення нових наукових досліджень.

Мета статті - здійснити правовий моніторинг застосування окремих положень законодавства України про функціонування військово-цивільних адміністрацій.

Основні результати дослідження. У даній статті пропонуємо розглянути ефективність окремих положень законодавства про ВЦА та можливі ризики їх застосування.

1. Визначення адміністративно-правового статусу ВЦА. У ст. 1 Закону України «Про військово-цивільні адміністрації» (далі - Закон) ВЦА визначені як тимчасові державні органи, що діють у складі Антитерористичного центру при Службі безпеки України [1; 2]. Виходячи з повноважень, якими наділено обласну та районну ВЦА та ВЦА населених пунктів, вони виконують незначну частину правоохоронних функцій, тому виникає потреба у визначенні чіткого співвідношення праворегулятивних та правоохоронних завдань ВЦА. Тобто постає питання про уточнення на законодавчому рівні визначення адміністративно-правового статусу ВЦА.

2. Зміна організаційно-правових повноважень ВЦА. Законом передбачено певні повноваження Антитерористичного центру при Службі безпеки України щодо вирішення кадрових питань діяльності ВЦА: 3 працівниками ВЦА населених пунктів Антитерористичний центр при Службі безпеки України укладає трудовий договір (ч. 4 ст. 3 Закону); керівник Антитерористичного центру при Службі безпеки України подає на затвердження Президенту України перелік посад у ВЦА населених пунктів та у районних, обласних ВЦА, на які призначаються особи з числа військовослужбовців військових формувань, особи рядового і начальницького складу правоохоронних органів (ч. 6 ст. 3 Закону); керівник Антитерористичного центру при Службі безпеки України призначає заступників керівників та керівників структурних підрозділів, а також затверджує структуру і штатний розпис ВЦА за поданням керівника відповідної ВЦА (чч. 8, 13 ст. 3 Закону); керівник районної, обласної ВЦА призначається на посаду та звільняється з посади Президентом України за поданням керівника Антитерористичного центру при Службі безпеки України (ч. 1 ст. 6 Закону); 
Муза О. В., Кубов Н. А. До питання про ефективність законодавчого регулювання діяльності...

керівник ВЦА населених пунктів призначається на посаду та звільняється з посади керівником обласної ВЦА за погодженням з керівником Антитерористичного центру при Службі безпеки України (ч. 2 ст. 6 Закону).

Такий підхід $є$ невиправданим з огляду на те, що Антитерористичний центр при Службі безпеки України не виконує функцій управління у сферах освіти, культури, охорони здоров'я та інших функцій загальної компетенції, які виконують місцеві державні адміністрації та органи місцевого самоврядування. Повноваження органів місцевого самоврядування, які законом покладено на ВЦА, мають місцеве значення і жодним чином не стосуються правоохоронної діяльності, компетенції Служби безпеки України. А звідси постає проблема співвідношення пропорційності повноважень ВЦА та органів місцевого самоврядування, адже, по суті, де-факто з початком функціонування ВЦА обмежені конституційні права територіальних громад на вирішення різноманітних питань місцевого значення [3].

У результаті, це може слугувати обмеженню інших конституційних прав і свобод людини і громадянина, що пов'язані з фактичним переходом до ВЦА повноважень органів місцевого самоврядування.

3. ВЦА та припинення повноважень органів місцевого самоврядування. Однією 3 підстав для утворення Президентом України ВЦА є нездійснення радами та/або їх виконавчими органами покладених на них повноважень (ч. 2 ст. 3 Закону). При цьому не враховується ситуація, коли у відповідному населеному пункті не здійснює своїх повноважень лише місцева рада, а ії виконавчі органи та відповідні голови (сільські, селищні, міські) навпаки функціонують [3]. У такому випадку слід застосовувати положення Закону України «Про місцеве самоврядування в Україні»- дострокове припинення повноважень сільської, селищної, міської, районної в місті, районної, обласної ради (ст. 78). Передбачено два способи дострокового припинення повноважень: 1) за рішенням місцевого референдуму; 2) за наявності підстав, передбачених ч. 1 ст. 78, рішення суду про визнання актів ради незаконними, висновків відповідного комітету парламенту, Верховна Рада України може призначити позачергові вибори сільської, селищної, міської, районної у місті, районної, обласної ради [4].

Зазначимо, що питання про призначення Верховною Радою України позачергових виборів сільської, селищної, міської, районної у місті, районної, обласної ради може порушуватись перед Верховною Радою України сільським, селищним, міським головою. У разі дострокового припинення повноважень ради позачергові місцеві вибори призначаються Верховною Радою України не пізніше ніж у дев'яностоденний строк $з$ дня дострокового припинення повноважень відповідної ради.

Варто зауважити, що Конституція України не передбачає ситуації, коли повноваження органів місцевого самоврядування, їх виконавчих органів припиняються взагалі. Закон про ВЦА не враховує конституційних гарантій місцевого самоврядування, а тому на практиці відбувається порушення окремих прав місцевого самоврядування.

Крім цього, відповідно до ч. 4 ст. 1 Закону, ВЦА наділені правами юридичної особи публічного права, що потребує їх державної реєстрації. Це положення стосується, як ВЦА населених пунктів, так і районних, обласних ВЦА. При цьому повноваження районних, обласних державних адміністрацій мають бути припинені Президентом України. Потрібно звернути увагу на те, що порядок припинення повноважень обласної та районної державних адміністрацій законодавством не визначений. Якщо під цим розуміється ліквідація цих органів, як юридичних осіб публічного права, то виникають проблеми з виконанням договірних зобов'язань, бюджетним фінансуванням, виконанням цільових програм та багато інших [3]. Крім цього, ліквідація районних та обласних державних адміністрацій суперечитиме Конституції України [5].

4. ВЦА та реалізація виключних повноважень місцевих рад. Виникає проблема реалізації повноважень, які виключно належать до компетенції місцевих рад. У такому контексті існує пропозиція щодо збільшення у діючому Законі повноважень ВЦА в частині вирішення питань місцевого значення, однак на нашу думку, індикатором ефективності таких змін до Закону має виступати їх конституційність. Варто додати, що ряд рішень в рамках місцевого самоврядування можуть прийматися місцевими радами на пленарних засіданнях, що відповідно створює процедурні перепони для реалізації ВЦА виключних повноважень органів місцевого самоврядування.

5. ВЦА, військово-цивільне адміністрування та запровадження нової посадової особи - військово-цивільного адміністратора. Для вирішення питань пошуку оптимальної моделі взаємовід- 
носин між ВЦА та органами місцевого самоврядування, запропоновано на рівні району, області повноваження відповідної ради залишити за районною, обласною ВЦА. Однак в селі, селищі, місті запровадити військово-цивільне адміністрування шляхом призначення військово-цивільного адміністратора як представника держави. Від імені держави в цьому випадку виступає орган державної влади - місцева державна адміністрація. Для села, селища, міста районного значення це районна державна адміністрація або районна ВЦА. Для міста обласного значення - це обласна державна адміністрація, або обласна ВЦА. ВЦА району, області, військово-цивільний адміністратор населеного пункту мають виконувати дві категорії повноважень - це додаткові повноваження у сферах безпеки, правопорядку та забезпечення життєдіяльності встановлені Законом і повноваження $з$ питань діяльності місцевих рад та сільських, селищних міських голів. Військово-цивільний адміністратор здійснює повноваження сільської, селищної, міської ради та відповідного голови, очолює виконавчий комітет цієї ради та апарат ради, вважається керівником ради та ії виконавчого комітету як юридичних осіб публічного права. Виконавчий комітет сільської, селищної, міської ради продовжує працювати під керівництвом військово-цивільного адміністратора. Виконавчі комітети місцевих рад всебічно забезпечують роботу військово-цивільного адміністратора. На рівні району, області ВЦА може утворюватися виключно для здійснення повноважень у сферах безпеки, правопорядку та забезпечення життєдіяльності. В такому разі відповідна районна, обласна рада, iii посадові особи та депутати продовжують здійснювати свої повноваження у повному обсязі [6].

3 наведених у цьому пункті пропозицій ключовим положенням є уведення у Закон поняття військово-цивільного адміністрування, як категорії, що передбачає нові можливості для здійснення ВЦА повноважень органів місцевого самоврядування. Крім цього, саме для територіальних громад сіл, селищ, міст пропонується створити нову посаду - військово-цивільного адміністратоpa, аби не призупиняти діяльність місцевих рад та їх голів. Тобто мова йде про запровадження так званого зовнішнього адміністрування в окремих територіях Донецької та Луганської областей, що з іншого боку, може свідчити й про «узаконення» повної підконтрольності органів місцевого самоврядування ВЦА.

Висновки. На підставі викладеного вважаємо, що створення військово-цивільних адміністрацій є виправданим та необхідним рішенням для врегулювання існуючих проблем пов'язаних iз виконанням відповідних обов'язків органами місцевого самоврядування та місцевими органами виконавчої влади на території проведення Операції Об'єднаних сил в умовах збройної агресії проти України. Зважаючи на те, що Закон України «Про військово-цивільні адміністрації» розроблявся та приймався у досить короткий проміжок часу і має ряд неточностей, слід наголосити на необхідності внесення змін та доповнень до нього з метою недопущення обмеження конституційних прав і свобод громадян, які $є$ жителями населених пунктів, в яких створені та функціонують військо-цивільні адміністрації. Необхідно збалансувати повноваження військово-цивільних адміністрацій та органів місцевого самоврядування з метою гарантування державою можливостей, передбачених Конституцією України для жителів територіальних громад Донецької і Луганської областей.

\section{Список використаних джерел}

1. Про військово-цивільні адміністрації : Закон України від 3 лютого 2015 року № 141-VIII [Електронний ресурс]. Режим доступу : http://zakon3.rada.gov.ua/laws/show/141-19

2. Про Службу безпеки України : Закон України від 25 березня 1992 року № 2229-XII [Електронний ресурс]. Режим доступу : http://zakon.rada.gov.ua/laws/show/2229-12

3. Пояснювальна записка до проекту Закону України «Про внесення змін до деяких законодавчих актів України (щодо особливостей статусу та здійснення повноважень військово-цивільних адміністрацій)» [Електронний pecypc]. Режим доступу : http://search.ligazakon.ua/__doc2.nsf/link1/GH2G91AA.html

4. Про місцеве самоврядування в Україні: від 21 травня 1997 року № 280/97ВР [Електронний ресурс]. Режим доступу : https://zakon.rada.gov.ua/laws/show/280/97-вр

5. Конституиія України: від 28 червня 1996 року № 254к/96-ВР [Електронний ресурс]. Режим доступу : http:// zakon.rada.gov.ua/laws/show/254 к'96-BP

6. Матеріали Комітету Верховної Ради України з питань державного будівництва, регіональної політики та місцевого самоврядування [Електронний ресурс]. Режим доступу : http://komsamovr.rada.gov.ua/documents 


\section{References}

1. The Law of Ukraine «On Civil-Military Administrations» of 03.02.2015 No141-VIII. URL: http://zakon3.rada.gov. ua/laws/show/141-19

2. The Law of Ukraine «On Security Service of Ukraine» of 22.03.1992 No2229-XII. URL: http://zakon.rada.gov.ua/ laws/show/2229-12

3. The Explanatory Note to the draft of Law of Ukraine «On Amendments to Certain Legislative Acts of Ukraine (regarding the peculiarities of status and the exercise of the functions by the civil-military administrations)». URL: http://search.ligazakon.ua/1_doc2.nsf/link1/GH2G91AA.html

4. The Law of Ukraine «On Local Self-Government in Ukraine» of 21.05.1997 No280/97VR. URL: https://zakon.rada. gov.ua/laws/show/280/97-вp

5. The Constitution of Ukraine of 28.06.1996. URL: http://zakon.rada.gov.ua/laws/show/254 к/96-BP

6. The materials of the Committee of the Verkhovna Rada of Ukraine on State Building, Regional Policy and Local Self-Government. URL:http://komsamovr.rada.gov.ua/documents

Муза О. В., Кубов Н. А. До питання про ефективність законодавчого регулювання діяльності військово-цивільних адміністрацій в Україні

Здійснено правовий моніторинг застосування окремих положень законодавства України про функціонування військово-цивільних адміністрацій. Розглянуто такі напрями законодавчого удосконалення діяльності військово-цивільних адміністрацій, як: уточнення адміністративного-правового статусу військово-цивільних адміністрацій; зміна організаційно-правових повноважень військово-цивільних адміністрацій; особливості припинення повноважень органів місцевого самоврядування в умовах функціонування військово-цивільних адміністрацій; проблеми реалізації повноважень, що належать виключно місцевим радам; запровадження військово-цивільного адміністрування та посадової особи у місцевих радах - військово-цивільного адміністратора. Акцентовано увагу на законодавчі ініціативи щодо запровадження зовнішнього публічного адміністрування в окремих територіях Донецької та Луганської областей. Зроблено висновок про необхідність збалансування повноважень військовоцивільних адміністрацій та органів місцевого самоврядування з метою гарантування державою можливостей, передбачених Конституцією України для жителів територіальних громад Донецької і Луганської областей.

Ключові слова: військово-цивільні адміністрації, права людини, публічне управління, виконавча влада, органи місцевого самоврядування.

Muza O. V., Kubov N. A. On the question of the efficiency of legislative regulation of the activity of civil-military administrations in Ukraine

In the article the legal monitoring of application of positions of legislation of Ukraine about civil-military administrations is carried out. The civil-military administrations are created with the aim of implementation of plenary powers of local selfgovernment bodies and local executive authorities, providing of security and normalization of the population's life, law and order, participation in counteracting to the acts of the armed aggression, diversionary displays, preventing humanitarian catastrophe. The authors considered such directions of legislative improvement of activity of civil-military administrations: the clarification of administrative-legal status of civil-military administrations; the changes of organizational and legal powers of civil-military administrations; the stopping of plenary powers of local self-government bodies in the conditions of functioning of civil-military administrations; the problems of realization of plenary powers, that exceptionally belonging for the local councils; the introduction of civil-military administration and new public officer in the local councils - civilmilitary administrator. The attention is emphasized to legislative initiatives in relation to the introduction of external public administration in separate territories of the Donetsk and Luhansk areas. In the article the problem of realization of plenary powers that is exceptionally belonging to the local councils is considered. In such context there is suggestion in relation to an increase the Law in force of plenary powers of civil-military administrations in part of decision of questions of local governing, the principle of the constitutionality must come forward as an indicator of efficiency of such changes. It should be added, that a number of decisions within the framework of local self-government bodies can be accepted by local councils in the plenary sessions, which accordingly creates procedural barriers for realization the exceptional plenary powers of local self-government bodies by civil-military administrations. In order to solve the question of search of optimal model of relationship between civil-military administrations and local self-government bodies, it proposed at the district and regional level the powers of corresponding councils to leave for the district and regional civil-military administrations. However, in the village, settlement and city it introduced the civil-military administration by setting of civil-military administrator as a representative of the state. It conclusion done about necessity to balance of plenary powers of civil-military administrations and local self-government bodies with the aim to guarantee the possibilities provided by the Constitution of Ukraine for the residents of territorial communities in the Donetsk and Luhansk areas.

Key words: civil-military administrations, human rights, public administration, executive power, local self-government bodies.

DOI: 10.33.66.3/2524-017X-2019-10-66-69 